\title{
Factors within the Business Regulatory Environment Affecting Entrepreneurial Activity in South Africa
}

\author{
Mazanai Musara \\ University of Limpopo, School of Education, \\ P. Bag X1106, Sovenga, 0727, South Africa \\ Email: jilgram@yahoo.com \\ Caleb Gwaindepi \\ University of Limpopo, School of Education \\ P.Bag X1106, Sovenga \\ Email: gwaindepi@gmail.com
}

Doi:10.5901/mjss.2014.v5n6p109

\begin{abstract}
The existing literature on factors affecting the level of entrepreneurship in South Africa has focused mainly on factors such as lack of finance, lack of education and business skills, crime, poor infrastructure and support system, among others and their influence on starting and survival of new businesses in South Africa. Despite the widely held contention that the business regulatory environment is among the chief factors hindering the entrepreneurial activity in South Africa, there is no/little empirical evidence to support this contention. Therefore, this paper investigates the factors within the businesses regulatory environment and their impact in the process of starting new businesses in South Africa. For this purpose a triangulation that involved both quantitative and qualitative research methods was employed. The results of the investigation revealed that bureaucracy, corruption, policy credibility, policy compliances and labour restrictions are the chief factors within the business regulatory environment that affect the process of starting new businesses. Furthermore, the study also found a positive and significance correlation between bureaucracy and corruption. Therefore, the study recommends policies to curb bureaucracy and corruption, flexibility in labour regulations, favourable compliance procedures as well as a more stable and credible policy environment that reduce hurdles in the process of starting new businesses.
\end{abstract}

Keywords: Business Regulatory Environment, New businesses, South Africa

\section{Introduction}

With high levels of unemployment and poverty in South Africa, entrepreneurship has been recognised as one of the most effective ways to address these challenges facing developing countries; South Africa included (Simrie, Herrington, Kew, and Turton, 2011; Herrington, Kew and Kew, 2010; Herrington, Kew, and Kew, 2009). Therefore endeavours to promote new businesses in South Africa should be considered to be of critical importance. Among other factors, restrictive legislative and regulatory conditions are viewed as critical constraints on the access of potential entrepreneurs into the business sector, and as obstacles to their growth (Department of Trade and Industries (DTI), 2005).

Simrie et al. (2011) revealed that $70.3 \%$ of experts interviewed cited government policies as a key constraint to entrepreneurial activity in South Africa. Government policies form part of the business regulatory and policy environment. Also given the enormous benefits of entrepreneurships in terms of reducing unemployment and alleviating poverty in South Africa, there is a dire need to create an entrepreneurship enabling environment. It is therefore imperative to examine the business regulatory environment in South Africa to assess its impact on the level of entrepreneurial activity.

The Global Entrepreneurship Monitor (GEM) surveys from 2002 to 2011 reviewed that the level of entrepreneurial activity as measured by the Total Entrepreneurial Activities (TEA) rate in South Africa is very low compared to other developed and developing nations (Simrie et al., 2011). In 2011, South Africa's TEA rate of $9.1 \%$ was significantly low as compared to other BRICS countries, Brazil and China with $14.9 \%$ and $24 \%$ respectively. With such a level of entrepreneurial activity, there is a need for an investigation of the purported factors leading to such low levels.

The regulatory environment has been identified (Dickson, Gates, Kapur, Seabury and Tally, 2007) as a controlling element for business to legally and freely function. In this study the business regulatory environment will be thought of in 
terms of legislation, political and administrative factors that have an influence on businesses. Consequently the role that business and corporate laws play in the formation, growth and transition of small-entrepreneurial ventures will be investigated.

Despite arguments by several scholars (Simrie et al., 2011; Herrington et al. 2010; Orford, Wood, Fischer, Herrington and Segal, 2003) that the business regulatory environment is not supportive to entrepreneurial activity in South Africa, there is little empirical evidence to support this contention. Several studies (Simrie et al., 2011; Herrington, et al., 2010; Herrington, et al., 2009, Maas and Herrington, 2006) also attempted to find solutions to other factors such as low levels of education, lack of access to finance, lack of or limited access to the necessary resources, poor infrastructure etc; and a little has been said about the business regulatory environment. It is paramount to note that even with availability of resources, skills and infrastructure, without addressing issues within the business regulatory environment, the much needed improve in entrepreneurial activity may not be achieved. Furthermore, none of these studies have attempted to identify and critically examine the specific factors within the business regulatory environment that hinder entrepreneurial activity in South Africa; this is the focus of this study.

\section{Research Problem}

Global Entrepreneurship Monitors (GEM) surveys from 2002-2011 revealed consistently low levels of entrepreneurial activities in South Africa (Simrie et al., 2011). The surveys also revealed that the level of entrepreneurial activity in South Africa is significantly low compared to the average of all the nations which participated in the GEM surveys in 2011. In a study, Rogerson (2000) opines that in sub-Saharan African countries there is no overall scarcity of entrepreneurs, therefore there is a need to create an entrepreneurship enabling environment in order to tap into enormous benefits brought in by new businesses in the form of job creation, poverty alleviation and economic growth.

Economic Commission for Africa (2001) emphasised the role of government in creating an enabling regulatory and policy environment for entrepreneurship. It recommended that the regulatory and policy environment should be such that it creates a stable fiscal and monetary policy setting with sustainable interest rates, a system of financial markets that provides incentives to save, and mechanisms to channel savings into investments. Furthermore, policies that minimise the cost of business licensing and registration while at the same time safeguarding public interests and policies that facilitate business transactions such as infrastructure development, were recommended. In another study, Porteous (2002) recommended assessing the impact of all new legislation to ensure that the costs and complexities of registration for new businesses are not increased by new legislation. Strengthening new business lobby groups and national audit of legislation affecting or constraining small businesses was also recommended (Porteous, 2002). An analysis of these recommendations point out that all other factors purported to be the reasons for low entrepreneurial activities in South Africa hinges on the business regulatory and policy environment.

Simrie et al., (2011) also argued that the business regulatory environment play a pivotal role in increasing the level of entrepreneurial activity. Among the BRICS countries (Brazil, Russia, India and South Africa) a 28\% increase in Brazil's entrepreneurship activities between 2006 and 2011 is attributed to its well-managed government policies to stimulate and support the development and growth of businesses, as well as numerous business policy reforms that have focused on making it easier to start businesses (Simrie et al.,2011). These show the importance of the business regulatory environment in increasing entrepreneurial activities of a nation.

The importance of the entrepreneurial environment as a stimulus to entrepreneurship should therefore not be underestimated. Furthermore, among the recommendations to improve entrepreneurship activities provided in the GEM 2011 South Africa's report (Simrie et al.,2011) was the need for an overhaul of the business regulatory environment. Therefore, this study is an investigation of the factors within the business regulatory environment that affect entrepreneurial activity in South Africa.

\section{Research Questions}

Despite pointing out the business regulatory environment as one of the major constraining factor on entrepreneurial activity in South Africa, with exception of expert opinions (Simrie et al.,2011), there is no sufficient empirical evidence to substantiate on that claim. Furthermore there is a failure to pinpoint the exact factors within the business regulatory environment affecting the level of entrepreneurial activity in South Africa. The fundamental questions therefore arise:

i. What factors within the business regulatory environment are constraining the levels of entrepreneurial activity in South Africa? 
ii. What are the gaps in the business regulatory environment which need to be closed to improve the level of entrepreneurial in South Africa?

iii. How best can South Africa fine tune its business regulatory environment to favour the much needed improvement in the level of entrepreneurship?

\section{Aim and Objectives of the Study}

The aim of this study is to contribute towards endeavours to improve entrepreneurial activity in South Africa. This will be done through the following objectives:

i. To investigate factors within the business regulatory environment that impact on entrepreneurial activity in South Africa;

ii. To identify gaps in the business regulatory environment which need to be closed to improve the level of entrepreneurial activity in South Africa, and

iii. To recommend ways to fine tune the business regulatory environment to favour the much needed improvement in the level of entrepreneurial activity in South Africa.

\section{The Importance of Entrepreneurship and Challenges Facing Entrepreneurs}

The importance of entrepreneurship and new businesses in particular is well-documented the world over as it makes significant contributions in addressing socio-economic problems such as unemployment, poverty, income inequalities, political stability and economic growth among others (DTI, 2005; Rogerson, 2005; Amini, 2004). There are however common sentiments in both developed and developing countries that the full potential of entrepreneurship is not being achieved in attempts to solve these problems (Bosma, Acs, Autio, Coduras and Levie, 2009). Therefore, in their study, Rogerson (2005) proposed the need for specific policy interventions which are designed to enhance the successful survival and growth of small business more especially in light of the structural difficulties in the business environment. Consequently, a lot of discussions and research ( for example Herrington, M. 2011; Simrie et al.,2011; Bosma et al., 2009; Herrington et al.,2009; Herrington et al.,2009) have been conducted on the factors impeding entrepreneurship in South Africa and other developing and developed countries. Several factors emerged as causes of low entrepreneurship and failure of new businesses, and these include lack of access to infrastructure, lack of access to finance, low managerial and business skills, crime, corruption and an unsupportive business regulatory environment (Simrie et al., 2011) to mention just a few. For more than two decades these factors were investigated by researchers, academics, scholars, policy makers, to find solutions to improve the level of entrepreneurship in South Africa. However, despite all these attempts, South Africa's level of entrepreneurship on average remain unsatisfactorily low and there is a high failure rate of new businesses (Maas and Herrington, 2006). In a study by Simrie et al (2011) and similar to other GEM surveys, amongst all other factors government policies were ranked $2^{\text {nd }}$ highest in terms of expert opinions on the factors impeding entrepreneurship in South Africa. However, despite the low levels of entrepreneurship, South Africa was ranked number 28 on the list of top 30 economies consisting mainly of developed countries, on ease of doing business (World Bank \& International Finance Corporation, 2012) which make it paradoxical. Therefore continuing debates around factors affecting entrepreneurial activity in South Africa become imminent. Consequent given that literature on factor with the business regulatory environment is scant, this study is an investigation on the factors within the business regulatory environment and their impacts on starting of new businesses.

\section{Impact of the Business Regulatory Environment}

Studies (Simrie et al., 2011; Maas and Herrington, 2006) revealed that the business regulatory environment is among the chief factor impeding the growth and survival of SMEs in South Africa. There are however, other studies which portray a different picture. For example, in 2012 on a regional ranking, South Africa ranked $2^{\text {nd }}$ after Mauritius and was ranked 36 on the all-rounder world ranking in terms of easy of doing business (few regulatory restrictions). In terms of starting a business in particular, South Africa was ranked number 44 (World Bank \& International Finance Corporation, 2012). This is an indication that South Africa has a promising potential of becoming one of the leading economics in the world. This is also to challenge the authenticity of claims that South Africa's business regulatory environment is among the most pressing obstacles to entrepreneurship. It is however important to note that to make the data comparable across economies, "Doing Business uses several assumptions about the business and the procedures. It assumes that all information is readily available to the entrepreneur and that there has been no prior contact with officials. It also assumes 
that all government and nongovernment entities involved in the process function without corruption. And it assumes that the business is a limited liability company, located in the largest business city and conducts general commercial or industrial activities" (World Bank \& International Finance Corporation, 2012). These assumptions may yield misleading results more particularly among small businesses which comprise the bulk of entrepreneurial activity in the South African context. Furthermore, World Bank and International Finance Corporation (2012) pointed out that higher rankings do not necessarily imply better legislation and this discredit the reliability of such rankings. Moreover, the source of their data and information, that is experts' opinions may window-dress the information portraying a wrong impression on the matter at hand. Furthermore, it was revealed (World Bank \& International Finance Corporation, 2012) that the surveys are restricted to limited liability companies and are not more concerned with the representative samples since it is not a statistical survey, thus the data is not generalizable to the whole of South Africa, more specially to the calibre and majority of entrepreneurship in the country. The most reliable sources of information are the entrepreneurs and potential entrepreneurs themselves. Therefore it remains necessary to investigate the loopholes in the business regulatory environment in order to make recommendations that aid in increasing the level of entrepreneurship in South Africa.

It is apparent that there are obstacles in the business regulatory environment that impede entrepreneurship in South Africa, however their extent and magnitude is yet to be investigated adequately. Venter, Urban and Rwigema (2011) pointed out that arbitrary enforcement and erratic administration laws act as barriers to new venture creation and hence to entrepreneurship. It was further argued that the more complex the procedure of registration or licensing a new business, the easier it is for governmental bureaucrats to abuse their power and impose their own discretion and complications for a new entrepreneurial venture. This is to argue that the problems in the business regulatory environment go beyond just mere laws and policies to further involve the associated criminal activities and corruption by political and other administrators. The influence of business regulatory environment can also go beyond the features of the regulation itself to include the procedural rules of the regulatory agency responsible for implementing the regulation.

Luthans, Stajkovic and Ibrayeva (2000) further asserts that the political and administrative discretion not only invites corruption but also generates uncertainty, making it difficult for potential entrepreneurs to plan and also leaves individual and property rights less secure. Such activities increase the risk associated with pursuing entrepreneurial activities and the risk factor is among the many reasons why several potential entrepreneurs are hesitant to pursue their dreams. This is a major deterrent factor to entrepreneurship.

South Africa has embarked on many important regulatory reforms to make it easier for potential entrepreneurs to start businesses. For example, in 2011 South Africa removed the requirement that entrepreneurs have to obtain legal assistance or have their incorporation documents notarized in the amendments to the Companies Act of 2008 (World Bank \& International Finance Corporation, 2012). Some of the changes include; less administration or red tape when registering a business, reduced financial reporting requirements for small businesses, enhanced protection for minority shareholders, introduction of a business rescue scheme, and provisions have been made for the early turnaround of businesses in financial trouble. This will prevent companies from going into major judicial management and also help to save jobs. These amendments also allow electronic submission of documents and publication, easing business start-up. Furthermore, in 2012 South Africa made starting a business easier by implementing its new company law, which eliminated the requirement to reserve a company name and simplified the incorporation documents (World Bank \& International Finance Corporation, 2012). It remains to be seen however as to whether these reforms are significant and sufficient enough to increase entrepreneurship in the country.

There is on-going concern that some regulations, rules, and government policies place a disproportionate burden on small businesses and entrepreneurs (Dixon, Gates, Kapur, Seabury and Talley, 2007). Further concerns are based on the argument that some of the regulatory reforms that are intended to support small businesses and entrepreneurship may not achieve the intended outcomes. Moreover, Dixon et al. (2007) further argued that the desire to support small businesses and entrepreneurship through regulatory reforms may come into conflict with the reason why the regulations were passed in the first place. For instance, most regulations were developed out of the concern about the effects of businesses on the society at large; this may be compromised out of the concern to increase entrepreneurship. This needs to be investigated in the case for South Africa.

Dixon et al. (2007) further questions the effects of special regulatory treatment on small businesses and new entrepreneurs. Questions raised include:

- Why and under what circumstances does special regulatory treatment for small businesses occur?

- Why does it take the specific form it takes?

- What objectives are it designed to serve, and how effective is it in achieving these objectives?

These are also critical questions which need to be answered about South Africa's business regulatory environment. Dixon et al. (2007) further point out that there is little/no quantitative evidence to demonstrate the specific 
impacts of policies and regulations on entrepreneurs; nor has there been much evidence showing whether rules and exemptions designed to benefit small businesses and entrepreneurs actually have that effect. Despite lack of empirical evidence, challenges in the business regulatory environment continue to emerge in literature as impediments to entrepreneurial activity in both developing and developed economies (Economic Commission for Africa, 2001; Herrington, 2011; Herrington et al., 2009).

Several regulatory issues were specifically noted for their impact on starting a business and notable among them are; restrictive labour regulations, inefficient government bureaucracy, corruption, and poor policy coordination and erratic administration of laws. According to the WEF Global Competitiveness Report (2013), Restrictive Labour Regulations contribute $18.5 \%$ of the challenges faced by new businesses in South Africa. This comprises of issues such as unemployment insurance and minimum wages that make it unsustainable for entrepreneurs to start a business. Inefficient government bureaucracy contributes $16.4 \%$, and it comprise of special regulatory treatment on small businesses and new entrepreneurs. This has the effect of breeding corruption and nepotism in the registering and administration of new businesses. In terms of Corruption, the International Corruption Perception Index 2012 ranked South Africa 9 ${ }^{\text {th }}$ in Africa and $69^{\text {th }}$ in the world with a score of 43 out of 100 indicating highly corrupt.

The amendment to the Companies Act of 2008 in 2011 saw the removal restrictive regulatory frameworks such as less administration or red tape when registering a business, reduced financial reporting requirements for small businesses, etc. However with the Licensing of Businesses Bill gazetted in 2013, in terms of ease of starting business South Africa fell 10 places to number 54. This may exhibit the impact of changes in the businesses regulatory environment on new businesses.

\section{Research Methodology}

This study is composed of two phases, viz the literature review phase and the empirical investigation. The literature review was done to identify factors within the business regulatory environment that are inhibiting entrepreneurship in South Africa. The sources used included journal articles, books, published and unpublished thesis and dissertations as well as websites such as of Doing Business and International Corruption Index.

The empirical study was approached from the perspective of a formal research design through the definition of the study population, the incorporation of suitable measuring instrument and reliable techniques for data analysis as stipulated in Cooper and Schindler (2008). The population of this study consisted of all new businesses owners in the Limpopo Province of South Africa. For the purpose of this study new businesses owners were defined as businesses that has been in operation for more than three months and less than three and half years (Simrie et al., 2011). The details of the populations was obtained from Statistics South Africa (StatSA) and Companies and Intellectual Properties Registration Commission (CIPRC). The study used the probability sampling method. The sample size was calculated using the Raosoft sample size calculator using a margin of error of 5\%, 95\% confidence levels and a $50 \%$ response distribution. The sample size calculator yielded a minimum recommended sample size of 153 new business owners. However, 200 questionnaires were distributed to provide for non-responses. The sample is small enough to allow for the feasibility of the study and yet large enough to be a true representative of the targeted population.

A 32 item questionnaire was developed from literature review and information from subject matter experts. Two subject matter experts were consulted and their suggestions and corrections were used to produce the final copy of the questionnaire. The Cronbach Alpha was used to measure the reliability of the research instrument. A reliability coefficient of 0.72 was obtained and according to Cooper and Schindler (2008) a reliability coefficient above 0.70 means the instrument is internally consistent.

Of the two hundred (200) questionnaires that were distributed, a hundred and fifty two (152) usable questionnaires were obtained, meaning a $76 \%$ response rate was obtained. Weighted mean and standard deviation were used to answer the research questions, while t-test statistic was used to test the hypothesis of no significant difference, with the ordinary least squares regression used to measure the linear relationship between the dependent and independent variables. Correlation between variables was tested using the Spearman correlation method. The following section presents the findings from the empirical investigation.

\section{Findings and discussion}

This section presents a summary of the results of the empirical investigation. For the sake of brevity, only a summary of the major findings are presented. 
Table 1: Regulatory factors impacting on new businesses

\begin{tabular}{|l|c|c|c|c|c|}
\hline \multicolumn{1}{|c|}{ Factor } & Strongly disagree & disagree & neutral & agree & Strongly agree \\
\hline Labour restrictions & 12.4 & 18.1 & 26.5 & 18.0 & 25.0 \\
\hline Corruption & 12.1 & 18.0 & 3.0 & 13.1 & 53.8 \\
\hline Bureaucracy & 3.4 & 12.2 & 5.0 & 13.5 & 67.3 \\
\hline Policy compliance & 22.5 & 25.2 & 15.2 & 12.3 & 25.0 \\
\hline Policy credibility & 23.1 & 16.9 & 20 & 13.7 & 26.3 \\
\hline
\end{tabular}

Table 1 shows the frequency distribution of the factors within the business regulatory environment that affect new businesses.

Figure 1: Regulatory factors impacting on new businesses

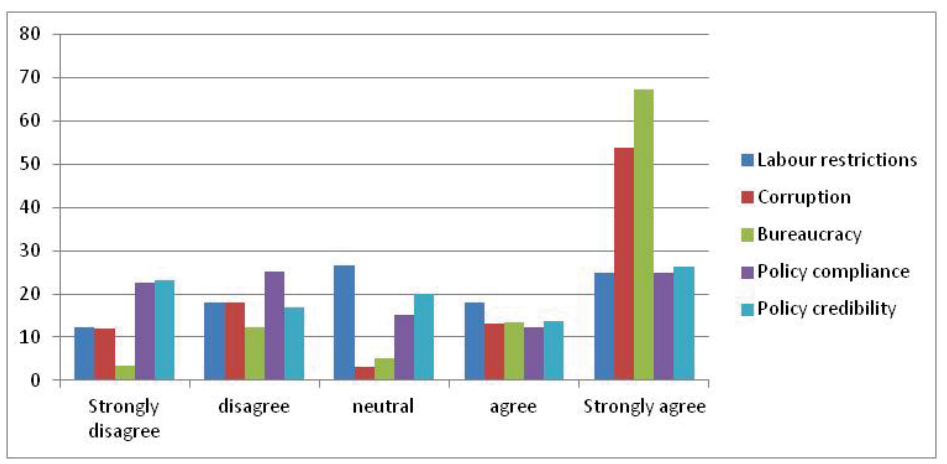

Table 2: Measures of dispersion

\begin{tabular}{|l|c|c|c|c|c|}
\hline & Labour restrictions & Corruption & Bureaucracy & Policy compliance & Policy credibility \\
\hline Mean & 14.7 & 16.39 & 15.57 & 15.21 & 20.06 \\
\hline Variance & 67.7 & 42.90 & 57.30 & 43.69 & 198.81 \\
\hline Standard Deviation & 8.23 & 6.55 & 7.57 & 6.61 & 14.10 \\
\hline
\end{tabular}

Table 3: Spearman Correlation of factors

\begin{tabular}{|l|c|c|c|c|c|}
\hline & Labour restrictions & Corruption & Bureaucracy & Policy compliance & Policy credibility \\
\hline \multirow{2}{*}{ Labour restrictions } & 1.000 & 0.025 & 0.032 & 0.004 & 0.012 \\
& .000 & .061 & .072 & .003 & .032 \\
\hline \multirow{2}{*}{ Corruption } & 0.025 & 1.000 & 0.891 & 0.576 & 0.324 \\
& .061 & .000 & .001 & .002 & .091 \\
\hline \multirow{2}{*}{ Bureaucracy } & 0.032 & 0.891 & 1.000 & 0.492 & 0.431 \\
& .072 & .001 & .000 & .023 & .063 \\
\hline \multirow{2}{*}{ Policy compliance } & 0.004 & 0.576 & 0.492 & 1.000 & -0.734 \\
& .003 & .002 & .023 & .000 & 0.001 \\
\hline \multirow{2}{*}{ Policy credibility } & 0.012 & 0.324 & 0.431 & -0.734 & 1.00 \\
& .032 & .091 & .063 & 0.001 & .000 \\
\hline
\end{tabular}

Sig. $=0.05 \mathrm{~N}=152$

A majority of new business owners singled out two factors; bureaucracy (approximately 80.8\%) and corruption (67\%) as factors with the greatest negative impact on starting businesses. Labour restrictions (43\%), Policy compliance (37.3\%) and policy credibility (40\%) had lower scores as compared to bureaucracy and corruption. These results suggest that bureaucracy and corruption are the main factors affecting new businesses in South Africa. This also confirmed by the means to these variables as shown in Table 2. Processes and delays in registering business (bureaucracy) may 
contribute towards corruption tendencies as entrepreneurs try to minimise delays. This is further supported by the positive correlation between the two factors $(r=0.891 ; p=0.001)$ (see Table 3). For example, the Licensing of businesses Bill (2013) requires all new businesses to register with their local municipalities and many of these municipalities lack the capacity to deal with added responsibilities the bill will impose on them (Mathoho, 2013). This will also give more power to the municipal officials and the police and in practice provide them with opportunities for intimidation and extortion of bribes leading to more corruptions tendencies.

Table 5: Multiple Regression Model

\begin{tabular}{|c|c|c|c|c|c|c|c|}
\hline \multicolumn{8}{|c|}{ Coefficients $^{a}$} \\
\hline \multirow{2}{*}{\multicolumn{2}{|c|}{ Model }} & \multicolumn{2}{|c|}{ UnStandardized Coefficients } & \multirow{2}{*}{\multicolumn{2}{|c|}{$\begin{array}{c}\text { Standardized Coefficients } \\
\text { Beta }\end{array}$}} & \multirow{2}{*}{$\mathrm{T}$} & \multirow{2}{*}{ Sig. } \\
\hline & & $B$ & Std. Error & & & & \\
\hline \multirow{6}{*}{1} & (Constant) & -.345 & .279 & & & -1.238 & .218 \\
\hline & Policy compliance & -.056 & .049 & & & -1.147 & .253 \\
\hline & Policy credibility & -.226 & .060 & & & -3.573 & .000 \\
\hline & Corruption & -.448 & .112 & & & -4.216 & .000 \\
\hline & Bureaucracy & -.646 & .093 & & & -6.925 & .000 \\
\hline & Labour restrictions & -.432 & .086 & & & -4.162 & .000 \\
\hline \multicolumn{8}{|c|}{ Dependent Variable: Entrepreneurship Activity } \\
\hline Model & $\mathrm{R}$ & \multirow{2}{*}{\multicolumn{2}{|c|}{ R Square }} & ed R Square & \multicolumn{3}{|c|}{ Std. Error of the Estimate } \\
\hline 1 & $.787^{a}$ & & & .611 & \multicolumn{3}{|c|}{.53565} \\
\hline
\end{tabular}

The results from Table 5 above show that four out of the five variables affect entrepreneurial activity negatively, as indicated by the negative coefficients and the significant $p$ values. Policy compliance is the only insignificant variable among the independent variables affecting starting of new businesses. Among the five variables, it can be noted that addressing Bureaucracy (Beta $=-.646$ ), corruption (Beta=-.448) and then labour restrictions (Beta=-.432) should take priority over policy credibility (Beta=-.226) and policy compliance (Beta $=-.056)$; if the much needed increase in new businesses is to be achieved. The long processes, procedures and requirements for registering new businesses, coupled with corruption tendencies, as supported by the International Corruption Perception Index (2012), and rigid labour laws dominated by unions have a significant negative impact on new businesses in South Africa. The Licensing of Businesses Bill gazetted in 2013, also explains the bureaucratic processes and lack of credibility because of policy inconsistencies and the administrative burden the new policy places on municipalities. This, according to Luthans, Stajkovic and Ibrayeva (2000) leads to political and administrative discretion which, not only invites corruption but also generates uncertainty, making it difficult for potential entrepreneurs to plan and also leaves individual and property rights less secure. This explains the significance of the bureaucracy, corruption and policy credibility variables in the model. The South African labour market is ranked by the World Economic Forum's Global Competitiveness Report as amongst the most restrictive in the world (World Bank \& International Finance Corporation, 2012). South Africa's labour laws have the rigidity more often found in developed markets with comparatively low levels of unemployment and the regulations act as a disincentive to potential direct foreign investment and the jobs that would otherwise come with these investments. This explains the negative significance of the labour restrictions variable in the model in explaining entrepreneurship. The $\mathrm{R}^{2}$ value shows that $62 \%$ of the behaviour and variability of the starting of new businesses is explained by the five explanatory variables.

\section{Conclusion}

Despite the richness of literature concerning challenges facing new businesses in South Africa, there is a lack of depth in many studies, particularly on the factor, business regulatory environment. This informed the need for empirical investigations to determine the extent and depth of this factor in as far as its implications on entrepreneurial activity and success is concerned. Furthermore, regulatory reforms to strengthen the entrepreneurship are necessary if the country is to achieve the much need increase in entrepreneurial activity levels and ultimately employment creation, poverty alleviation and sustainable economic growth.

Consequently this paper identifies and critically examine the loopholes in South Africa's business regulatory environment and recommend that issues surrounding bureaucratic processes as well as corruption should be addressed 
create an entrepreneurship enabling environment to benefit the nation in terms employment creation, poverty alleviation, economic growth and economic development at large.

Further examination of South Africa's entrepreneurship legal and policy framework is also recommended to ensure that it is carefully aligned to the objectives it is set for. This means rigorous evaluation of both existing and proposed policies; assess and attempt to close all the possible loopholes of each pierce of business legislation and policies in South Africa; establish their influence on entrepreneurship and finally with the aid of empirically investigations recommend changes and/or new policies to promote and support entrepreneurship in South Africa.

\section{References}

Amini, A. (2004). The distributional role of Small Businesses in Development.International Journal of Social Economics 31(4):370-383.

Angela and Motsa Associates, (2004). SMME Finance Sector Background Paper: A Review of key documents on SMME Finance 19942004. FinMark Trust: Johannesburg.

Bosma, N., Acs, Z.J., Autio, E., Coduras, A. \&Levie, J. (2009). Global Entrepreneurship monitor, 2008 Excutive Report. Babson Park: Babson College

Dixon L., Gates S.M.,Kapur K., Seabury, S.A.\& Talley E. (2007). The Impact of Regulation and Litigation on Small Businesses and Entrepreneurship: An Overview. In Gates, S.M \&Leuschner, K.J. (Eds). 2007. In the Name of Entrepreneurship? The Logic and Effects of Special Regulatory Treatment for Small Business, Pittsburgh: Rand Corporation.

DTI, (2005). Integrated strategy on promotion of entrepreneurship and Small businesses: Unlocking the potential of South African entrepreneurs [online] available at http://www.thedti.gov.za/sme_development/docs/strategy.pdfAccessed 04th July 2012.

Economic Commission for Africa (2001). Enhancing the Competitiveness of Small and Medium Enterprises in Africa: A Strategic Framework for Institutional Support

Herrington, M. (2011). Entrepreneurship: How can obstacles be overcome? In M. Mbeki (Ed.), Advocates forchange: How to overcome Africa's challenges (pp 115-135). Picador Africa.

Herrington, M., Kew, J., \& Kew, P. (2008). Global Entrepreneurship Monitor 2008 South African Report. Cape Town: Graduate School of Business, University of Cape Town.

Herrington, M., Kew, J., \& Kew, P. (2009).Tracking Entrepreneurship in South Africa: A GEM perspective. London: Global Entrepreneurship Research Association.

Herrington, M., Kew, J., \& Kew, P. (2010). Global Entrepreneurship Monitor 2010 South African Report. Cape Town: University of Cape Town Graduate School of Business.

Luthans, F., Stajkovic, A.D. \&lbrayeva, E. (2000). Environmental and Psychological challenges facing entrepreneurial development in transitional economies.Journal of World business, 35(1):95-117.

Maas, G. \& Herrington, M. (2006).Global entrepreneurship monitor South African Report. [Online].Available at http://www.gemconsortium.org/document.aspx?id756 [Accessed 6 June 2011].

Orford, J., Wood, E., Fischer, C., Herington, M. \& Segal, N. (2003). Global Entrepreneurship Monitor: South African Executive Report, Graduate School of Business, University of Cape Town, Cape Town.

Porteous. D. (2002). SMME Financing: Credit Providers Position Paper, [online] available atwww.finmark.org.zaAccessed 5 July 2012.

Rogerson, C.M. (2000). Successful SMEs in South Africa: the case of clothing producers in the Witwatersrand. Development Southern Africa 17(5):667-716.

Rogerson, C.M. (2005). SMME Development in Peripheral Regions: Manufacturing in Free State Province, South Africa Urban Forum, 16(1):35-54.

Schiffer, M. \&Weder B., (2001). Firm Size and the Business Environment: Worldwide Survey Results. Discussion Paper No. 43, Washington, D.C: International Finance Corporation.

Simrie, S., Herrington M., Kew J. \&Turton N. (2011). Global entrepreneurship Monitor 2011 South Africa. [online] available at http://www.gemconsortium.org/docs/download/2313 Accessed on 04th July 2012.

Timmons, J.A. \&Spinnel, S. (2004). New Venture Creation: Entrepreneurship for the 21st century. Boston: Irwin McGraw-Hill.

Venter, R., Urban, B. \&Rwingema H. (2011). Enterpreneurship: Theory in Practice. Cape Town: Oxford University Press.

World Bank \& International Finance Corporation. (2006). Doing Business in 2006. No 34550: Washington, DC.

World Bank \& International Finance Corporation. (2012). Doing Business in a more transparent world: Economy Profile-South Africa. Washington, DC:The International Bank for Reconstruction and Development. 